\title{
Ortaokullardaki Mülteci Öğrencilere Yönelik Öğretmen ve Öğrencilerin Tutumlarının İncelenmesi ${ }^{1}$
}

Ali KESKIN ${ }^{2}$
Veysel OKÇU³
Gönderim Tarihi: 06.03.2021
Kabul Tarihi: 16.04 .2021

Yayın Tarihi: 19.10 .2021

Öz: Bu araştırma, ortaokullardaki mülteci öğrencilere yönelik öğretmen ve öğrencilerin tutumlarını belirlemek amacıyla yapılmıştır. Araştırmanın evrenini, 2017-2018 eğitim-öğretim yılında Gaziantep ili Şahinbey ilçesinde bulunan toplam 97 ortaokulda görev yapan 3645 öğretmen ve yine bu okullarda öğrenim gören 85518 ortaokul öğrencisi oluşturmaktadır. Araştırmanın örneklemini ise, basit seçkisiz random (rastgele) yöntemiyle seçilen Gaziantep ili Şahinbey ilçesindeki 27 ortaokulda görev yapan 814 öğretmen ve bu okullarda öğrenim gören 1218 öğrencisi oluşturmaktadır. Araştırmada öğretmenler için "Mülteci Öğrenci Tutum Ölçeği" ve öğrenciler için ise "Mülteci Öğrencilere Yönelik Tutum Ölçeği" kullanılmıştır. Araştırmada, verilerin analizinde betimsel istatistik tekniklerinden frekans, yüzde, aritmetik ortalama, standart sapma, bağımsız örneklem t-testi ve ANOVA testi kullanılmıştır. Araştırmaya katılan öğretmenlerin, ortaokullardaki mülteci öğrencilere yönelik tutumlarının "iyi düzeyde" olduğu saptanmıştır. Buna ilaveten, öğretmenlerin mülteci öğrencilere iyimser yaklaştıkları, anlayışlı oldukları, kendilerini onların yerine koyarak onları anlamaya çalışıkları ve yaşadıklarından dolayı onlara adil davrandıkları tespit edilmiştir. Bununla birlikte, mülteci öğrencilerin dil farklılığı öğretmenler için sorun oluşturduğu, bu durum mülteci öğrencilerin sınıfa uyumlarını zorlaştırdığı ve öğretmenlerin mülteci öğrencilerin eğitiminde kendilerini yeterli görmedikleri belirlenmiştir. Araştırmaya katılan ortaokul öğrencilerinin, sınıfındaki mülteci öğrencilere yönelik tutumlarının "orta düzeyde" oldukları tespit edilmiştir. Ortaokulda öğrenim gören öğrenciler, mülteci öğrencilerin Türkçe'yi öğrenmelerinden mutlu oldukları, onlara bir yabancı gibi davranmadıkları, aynı dine mensup olmanın gereği olarak onlara yardımcı oldukları, mülteci öğrencilerin derslerinde başarılı olmaları kendilerini mutlu ettiği ve onlara Türkiye'yi tanıtmaktan da memnun oldukları saptanmıştır. Buna karşın, ortaokul öğrencilerinin ileriki eğitim-öğretim hayatlarında, okulda ve okul dışı günlük hayatlarında mülteci öğrencilerle arkadaşlık etmeye çok istekli olmadıkları ve benzer şekilde sınıf içinde yapılan eğitsel etkinliklerde mülteci öğrencilerle aynı grupta yer almak istemedikleri ortaya çıkmıştır.

\section{Anahtar Kelimeler: Ortaokul, Branş Öğretmeni, Tutum, Mülteci Öğrenci, Öğrenci \\ Investigation of Attitudes of Teacher and Students towards Refugee Students in the Middle Schools}

\begin{abstract}
This research was conducted to determine the attitudes of teachers and students towards refugee students in secondary schools. The universe of the research is 3645 teachers working in 97 secondary schools in Gaziantep province Şahinbey district in 2017-2018 academic year and 85518 secondary school students studying in these schools. The sample of the study consists of 814 teachers working in 27 secondary schools in Gaziantep province Şahinbey district selected by simple random random method and 1218 students studying at these schools. In the research, "Refugee Student Attitude Scale" was used for teachers and "Attitude Scale for Refugee Students" was used for students. In the study, frequency, percentage, arithmetic mean, standard deviation, independent sample t-test and ANOVA test were used in the analysis of data. The attitudes of the teachers participating in the research towards the refugee students in secondary schools were found to be "good". In addition, it has been determined that teachers approach the refugee students with optimism, are understanding, instead of them try to understand them by putting themselves, and treat them fairly. However, it has been determined that the language difference of refugee students is a problem for teachers, this makes it difficult for refugee students to adapt to the classroom and teachers do not consider themselves sufficient in the education of refugee students. It was determined that the attitudes of middle school students participating in the study towards the refugee students in their class were "at a medium level" but not at a "good level". Secondary school students are happy that refugee students learn Turkish, not treating them like a stranger, they help them as a requirement of belonging to the same religion, It has been determined that refugee students are successful in their lessons and they are happy to
\end{abstract}

${ }^{1}$ Bu çalışma, Doç. Dr. Veysel OKÇU'nun danışmanlığında yürütülen ve Ali KESKİN'in 2020 tarihinde hazırladığ 1 yüksek lisans tezine dayalı olarak hazırlanmıştır.

${ }^{2}$ MEB, Türkiye, keskinali352@gmail.com, ORCID: 0000-0002-8292-4455

${ }^{3}$ Siirt Üniversite, Türkiye, veysel.okcu56@gmail.com, ORCID: 0000-0003-3807-506X. 
introduce our country to them. On the other hand, it was revealed that middle school students were not very willing to be friends with refugee students in their future education and training life, at school and outside school, and similarly, they did not want to be in the same group with refugee students in educational activities held in the classroom.

Key Words: Secondary School, Branch Teacher, Attitude, Refugee Student, Student.

\section{GíRiş}

Uluslararası göç hem dinamik, hem karmaşık, hem çok boyutlu ve sürekli devinim halinde olan bir olgudur. Geçmişten günümüze birçok nedenden (siyasi, sosyal, ekonomik, güvenlik ve kültürel vb.) ötürü insanlar bireysel veya kitlesel olarak farklı coğrafyalara göç etmek durumunda kalmakta dolayısıyla bu durum hem toplumsal yapıyı etkilemekte hem de şekillendirmektedir (Massey, Arango, Hugo, Kouaouci, Pellegrino ve Taylor, 1998: 3). Çok yönlü ve karmaşık bir yapıya sahip olan göç hareketinin, toplumsal yaşamdaki demografik, kültürel, sosyo-ekonomik yapıyı biçimlendirmesi, göçün dinamik bir süreci ifade eden bir olgu olduğunu göstermektedir. Bir coğrafyadan başka bir coğrafyaya yapılan göç, sadece siyasi, kültürel, ekonomik yönlerle sınırlı değil, bireyin ve toplum edinmiş olduğu yaşama ve korunma ve katılım hakkından yoksun bırakan genel bir olgudur. İlk zamanlarda coğrafi sebepler, iklim koşulları, kıtlık gibi nedenlere bağlı yapılan göçler; günümüzde ise eğitim, ekonomik ve güvenlik gibi nedenler baz alınarak yapılmaya başlanmıştır.

Türkiye'yi etkileyen uluslararası göç hareketlerinden en kapsamlısı, Suriye'de yaşanmıştır. İlk sığınmacı Nisan 2011'de Suriye'den gelen 252 kişilik grupla başlamış, daha sonra yaşam şartlarının zorlaşması ve can güvenliği nedeniyle göç hareketi kitlesel boyuta ulaşarak milyonlarca kişiyi etkilemiştir (Akşit, Bozok ve Bozok, 2015: 92). Türkiye, Nisan 2011 tarihi itibariyle Suriye'ye yönelik "açık kapı politikasını" uygulamaya koyacağını duyurarak 100.000 kişiyi kabul edecek sınır olduğunu belirtmiş, ancak göç hareketi beklentinin çok ötesinde gerçekleşmiştir. Yerinden göç etmek durumunda kalan 10 milyon kadar sı̆̆ınmacının; 6.5 milyon kadarı kendi ülkesi içerisinde, 3.5 milyon kişi de başka ülkelere göç etmek zorunda kalmış kişiler, yani sı̆̆ınmacılardır (Yonca, 2014:26). UNICEF'in 2016 yılında yayınladığı rapora göre 2.764 .500 göçmen Türkiye'de kayıt altına alınmıştır ve bu sayının neredeyse yarısını 0 ila 18 yaş arasında olan çocuklar oluşturmaktadır. 860.000 kişi ise okula gitme yaşı gelmiş olan Suriyeli çocuklardır (İlksen Kanbur, 2017:2). Halen Türkiye'de 2018 yılı mart ayı itibarıyla 3.547.194 Suriyeli mülteci ülkemizde ikamet etmektedir (GIGM, 2018a). Bu kadar büyük bir kitlenin ülkemizde mülteci olarak yaşaması başta bu çocukların eğitimi olmak üzere birçok sorunu beraberinde getirmiştir. Suriye'de gerçekleşen çatışma ve iç savaşın sonucunda gerçekleşen zorunlu göçten en fazla çocuklar etkilenmiştir. Çocuklar bu süreçte hem psikolojik travmaları ile mücadele etmek hem de yoksulluk, barınma, sağlık, eğitim, dil, kültürel çatışma, ayrımcılık, istismar ve çok küçük yaşta evlilik gibi birçok sıkıntı ile mücadele etmek durumunda bırakılmışlardır. Aras ve Yasun'un (2016) yaptığı araştırmada, sağlanacak eğitim desteği ile Suriyeli çocukların kaygı ve yalnızlık gibi duygulardan uzaklaştırılabileceği, bunun yanı sıra çocuk işçiliği ve erken evliliklerin de önüne geçilebileceği belirtilmiştir. Suriye'den gelen ve göçe maruz kalan özellikle gelişme çağındaki çocukların verdikleri mücadele ve yaşadıkları problemler şüphesiz hayatlarında derin izler bırakmaktadır. Bununla beraber Coşkun ve Emin'in (2016) yaptığı araştırmada, Türkiye'deki Suriyeli mülteci çocukların devlet okullarında eğitim almalarının sosyal uyumun sağlanması açısından kritik bir öneme sahip olduğu belirtilmiş, ancak Suriyelilerin bu durumla ilgili kültürel asimilasyon kaygıları taşıdıkları da ortaya çıkmıştır.

Çocukluk çağından itibaren şekillenmeye başlayan tutumların oluşumu, bireyin yakın çevresiyle 
(anne, baba, akraba, arkadaş, okul ve öğretmenler vs.) etkileşimi sonucunda gerçekleşir. Tutumların oluşması belirli bir süreç aldığı gibi, tutumların değişmesi de tutumların dereceleri ile bağlantılıdır. Bireylerin tutumları ne kadar güçlü ise değişmesi de o kadar zor olacaktır (Kağıtçıbaşı, 2012:109). Zorunlu olarak göç eyleminde bulunan mültecilerin içerisinde bu durumdan en çok etkilenenler çocuklar olmaktadır. Dolayısıyla çocukların sağlıklı bir yaşam sürmesi ve geleceklerine yönelik kaygı ve korkuları gidermek, sosyalleşmelerini sağlamak ve edinmiş haklardan mahrum kalmamaları için Türkiye'de de eğitimle ilgili bazı politikalar izlenmektedir. Bu bağlamda, mülteci çocukların okulda sağlıklı bir şekilde sosyalleşebilmesi ve diğer gelişim alanlarında da sorunsuz bir şekilde gelişimini sürdürebilmesi için en önemli görev öğretmenlere düşmektedir (Pumariega, Rothe ve Pumariega 2005). Bu çocuklar için aktif olabilecekleri, akranlarıyla etkili bir iletişim içinde bulunabilecekleri ve kendini anlatabilecekleri çeşitli platformların olması, çocukların sağlıklı gelişime ve eğitimine önemli katkılar sağlayabilecektir. Bu nedenle öğretmenler, mülteci olan çocukların özellikle sosyalleşmesinde, diğer gelişim alanlarında ve özellikle de akademik başarıları üzerinde önemli bir etkiye sahiptirler (Reyes, Brackett, Rivers, White, \& Salovey, 2012). Bu nedenle, öğretmenlerin öğrenciler ve mülteci çocuklar için meydana getirdiği çevre ve etkileşimli ortam, onların başkalarının duygu ve düşüncelerini kavrayabilmeleri, kendi hislerini düzene koymaları ve yeteneklerini geliştirmeleri açısından önem taşımaktadır (Hyson, 2004). Bu nedenle, mülteci öğrencilerin günlük yaşamda aileden sonra en çok zamanlarını geçirdikleri kişiler, okuldaki akranları (öğrenciler) ve öğretmenlerdir. Dolayısıyla, bu mülteci öğrencilere karşı sınıftaki öğretmenlerin ve öğrenci arkadaşlarının tutumu da dikkate değer ve araştırılması gereken bir konudur.

Türkiye'de son yıllarda mültecilere ve öğrencilerin eğitimlerine yönelik yapılmış birçok araştırmanın (Akalın, 2016; Akdeniz, 2018; Alkurt, 2016; Bahadır ve Uçku, 2016; Bozkurt, 2018; Coşkun ve Emin, 2016; Erdem, 2017; Kultas, 2017; Köse, Bülbül ve Uluman, 2018; Sağlam ve Kanbur, 2017;Şirin ve Şirin, 2015; Şeker ve Aslan, 2015; Polat, 2012; Yiğit, 2015) olduğu görülmektedir. Konuyla ilgili alan literatür tarandığında, bu alanda yapılan çalışmaların özellikle öğretmen ve öğrencilerin tutumlarıyla ilgili arzu edilen düzeyde araştırmaların yapılmadığı ve yapılan bu çalışmayla alan literatüre katkı sağlanması da hedeflenmektedir. Tutumları belirleyen baskın faktörlerden biri de toplumsal algıdır. Mülteci öğrencilere yönelik öğretmenlerin ve öğrencilerin tutumlarını belirlemeye yönelik ortaokulda yapılmış araştırmaların az olması, yapılan bu çalışmanın literatüre katkı sağlayacağı öngörülmektedir. Mülteci öğrenciler için yürütülmesi gereken eğitim hizmetlerinde, içinde bulundukları sorunların anlaşılması, tespit edilmesi ve çözüm önerilerinde bulunulması büyük önem arz etmektedir.

\section{Araştırmanın Amacı}

$\mathrm{Bu}$ araştırmanın amac1, "Ortaokullarda öğrenim gören mülteci öğrencilere yönelik öğretmenlerin ve öğrencilerin tutumlarının ne düzeyde olduğunu belirlemektir. Bu bağlamda aşağıda belirtilen sorulara cevap aranmıştır.

1. Ortaokul öğretmenlerinin mülteci öğrencilere yönelik tutumları ne düzeydedir?

2. Ortaokul öğretmenlerinin mülteci öğrencilere yönelik tutumları; (1) cinsiyet, (2) medeni durum, (3) çocuk sahibi olma durumu (4) sendikaya üye olma durumu ve (5) sınıfında mülteci öğrenci olma durumu değişkenlerine göre anlamlı bir farklılık göstermekte midir?

3. Ortaokulda öğrenim gören öğrencilerin mülteci öğrencilere yönelik tutumları ne düzeydedir?

4. Ortaokulda öğrenim gören öğrencilerin mülteci öğrencilere yönelik tutumları, (1) cinsiyet, 
(2) sınıf düzeyi ve (3) sınıfında mülteci öğrenci olma durumu değişkenlerine göre anlamlı bir farklılık göstermekte midir?

\section{YÖNTEM}

\section{Araştırmanın Modeli}

$\mathrm{Bu}$ araştırma, ortaokullarda bulunan mülteci öğrencilere yönelik öğretmenlerin ve öğrencilerin tutumu belirlemeye yönelik olduğu için genel tarama modelinde gerçekleştirilmiştir. Tarama modeli, geçmişte ve halen var olan durumu var olduğu şekilde betimlemeyi amaçlayan bir araştırma yaklaşımıdır (Karasar, 2008). Araştırmada, öğretmenlere ve öğrencilere yönelik belirlenen kişisel değişkenler bağımsız değişken ve öğretmenlerin ve öğrencilerin tutumları ise bağımlı değişken olarak nitelendirilmiştir.

\section{Araştırma Grubu}

\section{Öğrenci Çalışma Grubu}

Bu araştırmanın evrenini, 2017-2018 eğitim ve öğretim yılında Gaziantep ili Şahinbey ilçesinde bulunan toplam 97 ortaokulda öğrenim gören e-okula kayıtlı 85518 öğrenci sayısı oluşturmaktadır. Evrendeki öğrenci sayılarına ilişkin veriler, Gaziantep Şahinbey İlçe Milli Eğitim Müdürlüğü’nden (2018) elde edilmiştir. Araştırmanın örneklemini ise 2017-2018 eğitim öğretim yılında basit seçkisiz random yöntemiyle seçilen Gaziantep ili Şahinbey ilçesindeki 28 ortaokulda öğrenim gören 654'ü (\%54) kadın, 564'ü (\%46) erkek olmak üzere toplam 1218 ortaokul öğrencisi oluşturmaktadır. Araştırmaya katılan ortaokul öğrencilerinin kişisel özellikleri ise aşağıdaki Tablo 2.2' de gösterilmektedir.

Tablo 1. Öğrencilerin Kişisel Özellikleri

\begin{tabular}{llcc}
\hline & & $\mathrm{N}$ & $\%$ \\
\hline \multirow{3}{*}{ Cinsiyet } & Kadın & 654 & 53.7 \\
\multirow{3}{*}{ Sınıf } & Erkek & 564 & 46.3 \\
& 6. sinıf & 468 & 38.4 \\
\hline Sınıfında Mülteci Öğrenci Olma & 7. sinıf & 329 & 27.0 \\
Durumu & 8. sinıf & 421 & 34.6 \\
\hline & Yok & 406 & 33.3 \\
& Toplam & 812 & 66.7 \\
\hline
\end{tabular}

Tablo 1'de görüldüğü gibi, araştırmaya katılan öğrencilerin \%54'ünün kadın, \%46'sinin erkek olduğu; \%38'inin 6. sınıf, \%27'sinin 7.sınıf, \%35'inin de 8.sınıf olduğu tespit edilmiştir. Öğrencilerin \%33'nün sınıfında mülteci öğrenci olduğu, \%67'sinin ise sınıfında mülteci öğrenci bulunmadığı görülmektedir.

\section{Öğretmen Çalışma Grubu}

Bu araştırmanın evrenini, 2017-2018 eğitim ve öğretim yılında Gaziantep ili Şahinbey ilçesinde bulunan toplam 97 ortaokulda görev yapan toplam 3645 öğretmenden oluşmaktadır. Evrendeki öğretmen sayılarına ilişkin veriler Gaziantep Şahinbey İlçe Milli Eğitim Müdürlüğü'nden (2018) elde edilmiştir. Araştırmanın örneklemini ise, 2017-2018 eğitim-öğretim yılında Gaziantep ili Şahinbey ilçesinde basit seçkisiz random yöntemi ile seçilen 27 ortaokulda görev yapan 486's1 
(\%60) kadın, 328'i (\%40) erkek olmak üzere toplam 814 ortaokul öğretmeni oluşturmaktadır. Araştırmanın örneklem grubuna ilişkin kişisel özellikler Tablo 2' de sunulmuştur.

Tablo 2. Araştırmaya Katılan Öğretmenlerin Kişisel Özellikleri

\begin{tabular}{|c|c|c|c|}
\hline \multicolumn{2}{|c|}{ Öğretmenlerin Demografik Özellikleri } & \multirow{2}{*}{$\begin{array}{c}\mathbf{N} \\
486\end{array}$} & \multirow{2}{*}{\begin{tabular}{|c|} 
\% \\
59.7
\end{tabular}} \\
\hline Cinsiyet & Kadın & & \\
\hline & Erkek & 328 & 40.3 \\
\hline \multirow{2}{*}{ Medeni Durum } & Bekar & 298 & 36.6 \\
\hline & Evli & 516 & 63.4 \\
\hline \multirow{4}{*}{ Kıdem } & $1-5$ yil & 321 & 39.4 \\
\hline & $6-10$ y1l & 237 & 29.1 \\
\hline & $11-15$ y1l & 139 & 17.1 \\
\hline & 16 yıl ve üzeri & 117 & 14.4 \\
\hline \multirow[t]{2}{*}{ Çocuk Sahibi Olma } & Var & 438 & 53.8 \\
\hline & Yok & 376 & 46.2 \\
\hline \multirow[t]{2}{*}{ Sendika Üyeliği } & Var & 538 & 66.1 \\
\hline & Yok & 276 & 33.9 \\
\hline \multirow{2}{*}{$\begin{array}{l}\text { Sınıfında Mülteci Öğrenci } \\
\text { Olma Durumu }\end{array}$} & Var & 552 & 67.8 \\
\hline & Yok & 262 & 32.2 \\
\hline Toplam & & 814 & 100.0 \\
\hline
\end{tabular}

Yukarıdaki tabloda görüldüğü gibi, araştırmaya katılan öğretmenlerin $\% 59,7^{\prime}$ si kadın ve \%40,3'ü ise erkektir. Katılımcıların \%36,6'sı bekâr, \%63,4'ü ise evlidir. Araştırmaya katılanların \%39,4'ü 1-5 yıl kıdeme, \%29,1'i 6-10 yıl kıdeme, \%17,1'i 11-15 yıl kıdeme ve \%14,4'ü ise 16 yıl ve üzeri kıdeme sahip olduğu görülmektedir. Araştırmaya katılan öğretmenlerin \%53,8'i çocuk sahibi ve $\% 46,2$ 'sinin ise henüz çocuk sahibi olmadıkları söylenebilir. Öğretmenlerin \%66,1'i herhangi bir sendikaya üyeliği mevcut, \%33,9'unun ise sendika üyeliği yoktur. Araştırmaya katılan öğretmenlerin \%67,8'inin sınıfında mülteci öğrenci var ve \%32,2'sinde ise sınıfında mülteci öğrenci bulunmamaktadir.

\section{Veri Toplam Araçları}

Öğretmenler için kullanılan ölçek Sağlam ve Kanbur (2017) tarafından geliştirilen "Mülteci Öğrenci Tutum Ölçeğidir (MÖTÖ)"'. Sağlam ve Kanbur (2017) tarafından bu ölçme aracının yapı geçerliliği için açımlayıcı faktör analizi ve doğrulayıcı faktör analizi yapılmıştır. Analiz sonuçlarına göre, ölçeğin 24 maddeden ve 3 boyuttan oluştuğu belirlenmiştir. Bu boyutlar; içeriğe ve kuramsal yapıya uygunluğu bakımından incelendiğinde birinci boyutun "iletişim", ikinci boyutun "uyum" ve üçüncü boyutun "yeterlik" şeklinde adlandırılabileceği görülmektedir. Bu faktörler "iletişim" (11 madde), "uyum" (9 madde), "yeterlik" (4 madde) olarak belirlenmiştir. Ölçek 4'lü Likert tipinde ve alınacak minimum puan 24 maksimum puan ise 96 puan olarak hesaplanmıştır. Aritmetik ortalamaların belirlenmesinde puan aralığı 1.00-1.74 "hiç katılmıyorum", 1.75-2.49 "biraz 
katılıyorum", 2.50-3.24 "çoğunlukla katılıyorum", 3.25-4.00 "tamamen katıliyorum" olarak belirlenmiştir. Sağlam ve Kanbur (2017) tarafından yapılan araştırmada mülteci öğrenci tutum ölçeğinin tamamı için hesaplanan Cronbach alpha iç tutarlık katsayısı .91 olarak belirlenmiştir. Bu araştırma da ise hesaplanan Cronbach alpha iç tutarlık katsayısı Tablo 3.3.'de gözlendiği gibi .82 olarak hesaplanıştır. Bu değer ölçeğin güvenilir bir ölçme aracı olduğunu ortaya koymaktadır. Bu araştırmada ise "Mülteci Öğrenci Tutum Ölçeği" ve alt boyutlarına ilişkin Croanbach alpha değerleri aşağıdaki Tablo 3’te gösterilmektedir.

Tablo 1. Mülteci Öğrenci Tutum Ölçeğine İlişkin Cronbach Alpha Değeri

\begin{tabular}{lll}
\hline Ölçekler & Cronbach Alpha Katsayısı & Madde Sayısı \\
\hline İletişim & .71 & 11 \\
Uyum & .75 & 9 \\
Yeterlik & .68 & 4 \\
Mülteci Öğrenci Tutum Ölçeği & .82 & 24 \\
\hline
\end{tabular}

Tablo 3'te görüldügü gibi ölçeğin tamamının ve boyutlarının güvenirlik katsayıları oldukça güvenilir düzeydedir. En yüksek değeri .75 ile uyum boyutu oluştururken en düşük değer .68 ile yeterlik boyutu oluşturmaktadır. Aşağıdaki Tablo 2.4.'de Mülteci Öğrencilere Yönelik Öğretmenlerin Tutumlarını belirlemeye yönelik Ölçeğe ilişkin normallik testi sonuçları yer almaktadır.

Tablo 2. Mülteci Öğrenci Tutum Ölçeği ve alt boyutlarına ilişkin normallik testi

\begin{tabular}{lll}
\hline Ölçek & Çarpiklık (Skewness) & Basıklık (Kurtosis) \\
\hline İletişim & -.400 & .889 \\
Uyum & -.202 & -.189 \\
Yeterlik & .231 & -.356 \\
Toplam & -.186 & .211 \\
\hline
\end{tabular}

Yapılan normallik testi \%95 güven düzeyinde gerçekleştirildiğinden ölçeklere ilişkin çarpıklık ve basıklık değerlerinin -1,96 ile 1,96 (-1 ile 1 aralığını kabul eden kaynaklara da rastlamak mümkün) aralığında olması halinde normal dağılıma sahip oldukları, bu aralığın dışında olmaları halinde ise normal dağılıma sahip olmadıkları sonucuna ulaşılmaktadır. Tablolar incelendiğinde hem ana ölçek hem de alt boyutları için çarpıklık basıklık değerlerinin literatürde yer alan her iki aralığında içerisinde yer aldığı görülmektedir. Buna göre \%95 güven düzeyinde ölçek normal dağılıma sahiptir sonucuna ulaşılmaktadır.

Ortaokul öğrencileri için kullanılan ölçek Kılcan, Çepni ve Kılınç (2017) tarafından geliştirilen “Mülteci Öğrencilere Yönelik Tutum Ölçeğidir (MÖYTÖ)". Ölçekte yer alan 3, 8, 15 ve 24. maddeler ters maddeler olup bu maddeler veri analizinde ters puanlanarak hesaplanmıştır. Ölçek 3'lü Likert tipinde ve alınacak minimum puan 24 maksimum puan ise 72 puan olarak hesaplanmıştır. Aritmetik ortalamaların belirlenmesinde puan aralığı 1-1.66 arası katılmıyorum, 1.67-2.33 arası kararsızım ve 2.34-3 arası katılıyorum olarak belirlenmiştir. Mülteci öğrencilere yönelik tutum ölçeğinin tamamı için hesaplanan Cronbach alpha iç tutarlık katsayısın 96 olarak belirlenmiştir. Buna dayanarak ölçeğin .80 'den yüksek bir değer aldığ1 ve bu ölçeğin yüksek güvenilir bir ölçek sahip olduğu söylenebilir (Özdamar, 2004). Yapılan bu araştırmada "Mülteci Öğrencilere Yönelik Tutum Ölçeğine" ait hesaplanan Croanbach alpha değerleri aşağıdaki Tablo 5'te gösterilmektedir. 
AJER - Academia Eğitim Araştırmaları Dergisi 2021, 6(2), 311-332

https://dergipark.org.tr/pub/egitim e-ISSN 2619-9351

Tablo 3. Mülteci Öğrencilere Yönelik Tutum Ölçeğine Ait Cronbach Alpha Değeri

\begin{tabular}{lll}
\hline Ölçekler & Cronbach Alpha & Madde sayısı \\
\hline Mülteci Öğrencilere Yönelik Tutum Ölçeği & .86 & 24 \\
\hline
\end{tabular}

Tablo 5 'te görüldüğü gibi, ölçeğin güvenirlik katsayı değeri .86 olarak hesaplanmış ve bu durum ölçeğin güvenilir olduğunu göstermektedir. Aşağıdaki Tablo 6'da ise "Mülteci Öğrencilere Yönelik Tutum Ölçeğine (MÖYTÖ)" ilişkin normallik testine ait sonuçlara yer verilmiştir.

Tablo 4. Mülteci öğrencilere yönelik tutum ölçeğine ilişkin normallik testi

\begin{tabular}{lll}
\hline Ölçek & Çarpıklık (Skewness) & Basıklık (Kurtosis) \\
\hline Öğrenci & -.561 & -.089 \\
\hline
\end{tabular}

Yapılan normallik testi \%95 güven düzeyinde gerçekleştirildiğinden ölçeklere ilişkin çarpıklık ve basıklık değerlerinin -1,96 ile 1,96 (-1 ile 1 aralığını kabul eden kaynaklara da rastlamak mümkün) aralığında olması halinde normal dağılıma sahip oldukları, bu aralığın dışında olmaları halinde ise normal dağılıma sahip olmadıkları sonucuna ulaşılmaktadır. Tablo 2.6. incelendiğinde çarpıklık basıklık değerlerinin literatürde yer alan her iki aralığında içerisinde yer aldığı görülmektedir. Buna göre \%95 güven düzeyinde ölçek normal dağılıma sahip olduğu sonucuna ulaşılmaktadır.

\section{Verilerinin Toplanması ve Analizi}

Ölçekler, okul idaresinin bilgisi dahilinde gösterilen "araştırma izin" belgesi gösterilerek öğretmenlere ve öğrencilere uygulanmış olup, araştırmaya katılım gönüllülük esasına göre gerçekleştirilmiştir. Gaziantep Şahinbey ilçesine bağlı toplam 97 ortaokul bulunmaktadır. Evrenden örneklem alma yoluyla 27 ortaokula rastgele gidilmiştir. Öğretmenlere 850 ölçek dağıtılarak bunlardan 36 tanesi eksik ya da geçersiz durumlardan dolayı çıkartılmıştır. Öğretmenlerden elde edilen toplam 814 veri analize tabi tutulmuştur. Öğrencilere ise öğretmenlerden yardım ve destek alınarak 6. 7. ve 8. sınıfa toplam 1300 ölçek dağıtılmış, 1218 veri analiz edilmeye uygun bulunmuş, 82 tanesi ise eksik yada geçersiz durumlardan dolayı analize tabi tutulmamıştır. Araştırmada kullanılan ölçeklerdeki veriler gerekli istatistiksel çözümlemelerden yararlanılmıştır. Araştırmaya katılanların demografik bilgilerini, yüzde ve frekans puanları hesaplanmıştır. Araştırmada verilerin dağılımını nasıl olduğunu bulmak için basıklık çarpıklık değerlerine bakılmış, değerlerin +2 ile -2 arasında ki değerlere sahip olduğu (George ve Mallery, 2010) görülmüş ve dağılımın normal olduğuna karar verilmiştir. Bağımsız değişkenlerin 2 olduğu gruplarda t-testi, bağımsız değişkenlerin 2'den fazla gruplarda ise ANOVA testi kullanılmıştır. Değişkenler arasında anlamlı farklılı̆̆ın olması durumunda bu anlamlı farklılığın kaynağı Tukey testi ile belirlenmiştir. Anlamlılık düzeyi $\mathrm{p}<.05$ olarak hesaplanmıştır. Elde edilen bulgular \% 95 güven aralığında ve \%5 anlamlılık düzeyinde değerlendirilmiştir. 


\section{BULGULAR}

\section{Ortaokullarda Öğrenim Gören Mülteci Öğrencilere Yönelik Öğretmenlerin Tutumlarına İlişkin Bulgular}

Öğretmenlerin ortaokullarda öğrenim gören mülteci öğrencilere yönelik tutumlarına ait hesaplanan aritmetik ortalama ve standart sapma değerleri aşağıdaki Tablo 3.1.'de gösterilmektedir.

Tablo 7. Ortaokullardaki mülteci öğrencilere yönelik öğretmenlerin tutumlarına ilişkin aritmetik ortalama ve standart sapma değerlerine ait bulgular

\begin{tabular}{lllll}
\hline Ölçeğin Alt Boyutları & $\mathbf{N}$ & $\boldsymbol{x}^{-}$ & Ss & Alg1 üzeyi \\
\hline İletişim & 814 & 3.29 & .33 & Çok Iyi \\
\hline Uyum & 814 & 2.77 & .43 & Iyi \\
\hline Yeterlik & 814 & 2.66 & .57 & Iyi \\
\hline MÖTÖ (Toplam) & 814 & 2.98 & .31 & Iyi \\
\hline
\end{tabular}

Yukarıdaki tablo incelendiğinde, ortaokullardaki mülteci öğrencilere yönelik öğretmenlerin tutumları genel olarak ( $\chi=2.98$ ) "çoğunlukla katılıyorum" diğer bir ifadeyle "iyi düzeyde" oldukları tespit edilmiştir. Araştırmaya katılan öğretmenlerin mülteci öğrencilere yönelik tutumları iletişim alt boyutunda ( $X=3.29)$ "tamamen katılıyorum" diğer bir ifade ile çok iyi düzeyde olduğu, uyum $(x=2.77)$ ve yeterlik alt boyutlarında ise $(x=2.66)$ "çoğunlukla katılıyorum" düzeyinde yani "iyi düzeyde" oldukları belirlenmiştir. Ölçekteki alt boyutların ortalama puanları ise en yüksek ortalama puanın "iletişim" $(X=3.29)$ alt boyutunda, en düşük ortalama puanın ise yeterlik $(x=2.66)$ alt boyutunda olduğu belirlenmiştir. Buna göre öğretmenlerin mülteci öğrencilere yönelik tutumlarının genel olarak iyi düzeyde olması ve özelliklede "iletişim alt boyutunda "çok iyi" düzeyde olması olumlu ve ümit verici bir bulgu olarak değerlendirilebilir. Buna ilaveten, öğretmenlerin mülteci öğrencilere yönelik tutum puanlarının en yüksek ve en düşük olan maddelerden bazıları aşağıdaki Tablo 8'de gösterilmektedir.

Tablo 8. Mülteci Öğrenci Tutum Ölçeği (MÖTÖ) maddelerine ilişkin aritmetik ortalama ve standart sapma değerleri

\begin{tabular}{lllll}
\hline Sıra & En Yüksek Olan Maddeler & $\mathbf{N}$ & $\boldsymbol{X}^{-}$ & \multicolumn{2}{c}{ Ss } \\
\hline 1 & M8.Öğrencilerimin mülteci öğrencilere olumlu davranmalarını sağlarım & 814 & 3.5 & .56 \\
2 & M2. Uyumda güçlük yaşayan mülteci öğrencilere hoşgörülü davranırım & 814 & 3.47 & .58 \\
3 & M3. Mülteci öğrencileri anlamaya çalışırım & 814 & 3.41 & .58 \\
4 & M1. Mülteci öğrencilere önyargısız yaklaşırım & 814 & 3.39 & .74 \\
5 & M6. Mülteci öğrencilere diğer öğrencilere davrandı̆̆ım gibi davranırım & 814 & 3.37 & .62 \\
\hline Sıra & En Yüksek Olan Maddeler & $\mathbf{N}$ & \multicolumn{1}{|c}{} & \multicolumn{2}{|c}{ Ss } \\
\hline 1 & M18. Mülteci öğrenciler sınıfa uyumludur & 814 & 2.48 & .77 \\
2 & M23. Mülteci öğrencilerin eğitiminde yeterli olduğumu düşünürüm & 814 & 2.42 & .79 \\
3 & M24.Mülteci öğrencilerin dil farklılığı benim için sorun oluşturmaz & 814 & 2.16 & .91 \\
\hline
\end{tabular}

Araştırmaya katılan öğretmenlerin mülteci öğrencilere yönelik tutum ölçeğindeki maddelerin ortalamasına baktığımızda en yüksek puan sırasıyla; “Öğrencilerimin mülteci öğrencilere olumlu 
davranmalarını sağlarım” ( $\left.\chi^{-}=3.5\right)$ tamamen katılıyorum, “Uyumda güçlük yaşayan mülteci öğrencilere hoşgörülü davranırım” ( $\left.\chi^{-}=3.47\right)$ tamamen katılıyorum, "Mülteci öğrencileri anlamaya çalışırım" ( $\overline{x=3.41)}$ tamamen katılıyorum, “Mülteci öğrencilere önyargısız yaklaşırım” $(\overline{x=3.39})$ tamamen katılıyorum, "Mülteci öğrencilere diğer öğrencilere davrandı̆̆ım gibi davranırım" $\left(\chi^{-}=3.37\right)$ tamamen katılıyorum düzeyinde; en düşük puana ise "Mülteci öğrenciler sınıfa uyumludur" ( $\left.\chi^{-}=2.48\right)$ biraz katılıyorum, “Mülteci öğrencilerin eğitiminde yeterli olduğumu düşünürüm" ( $\overline{\left.\chi_{=}=2.42\right)}$ biraz katılıyorum, "Mülteci öğrencilerin dil farklılığı benim için sorun oluşturmaz" ( $\overline{X=2.16)}$ ) "biraz katılıyorum" düzeyinde bir tutuma sahip oldukları görülmektedir. Bu ölçekte en yüksek ortalamaya sahip olan ilk 5 madde sırasıyla 8., 2., 3., 1. ve 6. maddeler (tamamen katılıyorum), en düşük ortalamaya sahip olan son 3 madde ise sirasıyla 18., 23. ve 24. maddeler (biraz katılıyorum) olduğu belirlenmiştir. Buna göre, öğretmenlerin mülteci öğrencilere karşı iyimser yaklaştıkları, anlayışlı oldukları, kendilerini onların yerine koyarak onları anlamaya çalıştıkları ve yaşanılan travmadan dolayı onlara önyargısız yaklaşarak hoşgörülü davrandıkları tespit edilmiştir. Bununla birlikte, mülteci öğrencilerin dil farklılığı öğretmenler için sorun oluşturduğu, bu durum mülteci öğrencilerin sınıfa uyumlarını zorlaştırdığı, öğretmenlerin mülteci öğrencilerin eğitiminde kendilerini yeterli görmedikleri belirlenmiştir.

Cinsiyet Değişkenine Göre Ortaokullarda Öğrenim Gören Mülteci Öğrencilere Yönelik Öğretmenlerin Tutum Düzeylerine İlişkin Bulgular

Cinsiyet değişkenine göre mülteci öğrencilere yönelik öğretmenlerin tutumlarına ilişkin bulgular Tablo 9'da sunulmuştur.

Tablo 9. Öğretmenlerin cinsiyet değişkenine göre ortaokullarda öğrenim gören mülteci öğrencilere yönelik tutumlarına ilişkin t- testi sonuçları

\begin{tabular}{|c|c|c|c|c|c|c|}
\hline Boyutlar & Cinsiyet & $\mathbf{N}$ & $x^{-}$ & Ss & $\mathbf{t}$ & p \\
\hline \multirow[t]{2}{*}{ İletişim } & Kadın & 486 & 3.290 & .32 & \multirow{2}{*}{.103} & \multirow{2}{*}{.918} \\
\hline & Erkek & 328 & 3.292 & .34 & & \\
\hline \multirow[t]{2}{*}{ Uyum } & Kadın & 486 & 2.770 & .43 & \multirow{2}{*}{.332} & \multirow{2}{*}{.740} \\
\hline & Erkek & 328 & 2.780 & .43 & & \\
\hline \multirow[t]{2}{*}{ Yeterlik } & Kadın & 486 & 2.621 & .56 & \multirow[b]{2}{*}{.056} & \multirow[b]{2}{*}{.955} \\
\hline & Erkek & 328 & 2.624 & .58 & & \\
\hline \multirow[b]{2}{*}{ Toplam } & Kadın & 486 & 2.984 & .31 & \multirow[t]{2}{*}{.237} & \multirow[t]{2}{*}{.812} \\
\hline & Erkek & 328 & 2.999 & .32 & & \\
\hline
\end{tabular}

${ }^{*} \mathrm{p} \leq .05$

Öğretmenlerin, mülteci öğrencilere yönelik tutumları cinsiyete göre anlamlı fark olup olmadığına ilişkin yapılan t-testi sonuçlarına göre, öğretmenlerin cinsiyete göre "iletişim", "uyum" ve "yeterlik" alt boyutlarında ve genel toplamda aralarında istatistiksel olarak anlamlı bir farklılık olmadığı saptanmıştır. Buna göre, araştırmaya katılan öğretmenlerin mülteci öğrencilere yönelik tutumları arasında cinsiyet faktörünün etkili olmadığı söylenebilir. 


\section{Medeni Durum Değişkenine Göre Ortaokullarda Öğrenim Gören Mülteci Öğrencilere Yönelik Öğretmenlerin Tutumlarına İlişkin Bulgular}

Medeni Durum değişkenine göre öğretmenlerin mülteci öğrencilere yönelik tutumlarına ilişkin bulgular Tablo 9'da sunulmuştur.

Tablo 10. Ö̆̆retmenlerin medeni durum değişkenine göre ortaokullarda öğrenim gören mülteci öğrencilere yönelik tutumlarına ilişkin t-testi sonuçları

\begin{tabular}{|c|c|c|c|c|c|c|}
\hline Boyutlar & Medeni Durum & $\mathbf{N}$ & $x^{-}$ & Ss & $\mathbf{t}$ & $\mathbf{P}$ \\
\hline \multirow[t]{2}{*}{ İletişim } & Bekar & 298 & 3.31 & .34 & \multirow{2}{*}{1.729} & \multirow{2}{*}{.084} \\
\hline & Evli & 516 & 3.27 & .32 & & \\
\hline \multirow[t]{2}{*}{ Uyum } & Bekar & 298 & 2.72 & .43 & \multirow{2}{*}{2.260} & \multirow{2}{*}{.024} \\
\hline & Evli & 516 & 2.80 & .43 & & \\
\hline \multirow[t]{2}{*}{ Yeterlik } & Bekar & 298 & 2.65 & .58 & \multirow{2}{*}{1.379} & \multirow{2}{*}{.168} \\
\hline & Evli & 516 & 2.60 & .56 & & \\
\hline \multirow[t]{2}{*}{ Toplam } & Bekar & 298 & 2.98 & .32 & \multirow{2}{*}{0.099} & \multirow{2}{*}{.922} \\
\hline & Evli & 516 & 2.98 & .31 & & \\
\hline
\end{tabular}

$$
{ }^{*} \mathrm{p} \leq .05
$$

Öğretmenlerin mülteci öğrencilere yönelik tutumları evli ya da bekar olmalarına göre aralarında anlamlı bir farkın olup olmadığına ilişkin yapılan t-testi sonucunda ise, öğretmenlerin medeni durum değişkenine göre "iletişim", "yeterlik" alt boyutlarında ve genel toplamda aralarında istatistiksel olarak anlamlı bir farklılık olmadığı belirlenmiştir. Ancak, araştırmaya katılan öğretmenlerin evli ya da bekar olma durumuna göre mülteci öğrencilere yönelik tutumları uyum alt boyutunda aralarında istatistiksel olarak anlamlı bir farkın olduğu gözlenmiştir. Bu anlamlı farklılığın ise evli öğretmenler lehine olduğu tespit edilmiştir. Buna göre evli olan öğretmenlerin mülteci öğrencilere yönelik uyum alt boyutundaki tutumlarının daha olumlu yönde olduğu söylenebilir.

\section{Çocuk Sahibi Olma Durumuna Göre Ortaokullarda Öğrenim Gören Mülteci Öğrencilere Yönelik Öğretmenlerin Tutumlarına İlişkin Bulgular}

Çocuk sahibi olan ve olmayan öğretmenlerin mülteci öğrencilere yönelik tutumlarına ilişkin yapılan t-testi sonuçları aşağıdaki Tablo 11'de gösterilmektedir.

Tablo 11. Öğretmenlerin çocuk sahibi olma durumuna göre ortaokullarda öğrenim gören mülteci öğrencilere yönelik tutumlarına ilişkin bağımsız t- testi sonuçları

\begin{tabular}{|c|c|c|c|c|c|c|}
\hline \multirow[t]{2}{*}{ Boyutlar } & \multicolumn{6}{|l|}{ Çocuk Sahibi } \\
\hline & Olma Durumu & $\mathbf{N}$ & $\bar{x}$ & Ss & $\mathbf{t}$ & p \\
\hline \multirow[t]{2}{*}{ İletişim } & Var & 438 & 3.26 & .32 & \multirow{2}{*}{2.089} & \multirow{2}{*}{.04} \\
\hline & Yok & 376 & 3.31 & .33 & & \\
\hline \multirow[t]{2}{*}{ Uyum } & Var & 438 & 2.78 & .43 & \multirow{2}{*}{0.540} & \multirow{2}{*}{.56} \\
\hline & Yok & 376 & 2.76 & .43 & & \\
\hline \multirow[t]{2}{*}{ Yeterlik } & Var & 438 & 2.58 & .56 & \multirow{2}{*}{1.936} & \multirow{2}{*}{.04} \\
\hline & Yok & 376 & 2.66 & .57 & & \\
\hline \multirow[t]{2}{*}{ Toplam } & Var & 438 & 2.97 & .31 & \multirow{2}{*}{1.287} & \multirow{2}{*}{.19} \\
\hline & Yok & 376 & 3.00 & .31 & & \\
\hline
\end{tabular}

${ }^{*} \mathrm{p} \leq .05$ 
Çocuk sahibi olan ve olmayan öğretmenlerin mülteci öğrencilere yönelik tutumları arasında yapılan t-testi sonucunda ise, iletişim ve yeterlik alt boyutlarında aralarında istatistiksel olarak anlamlı bir farklılık olduğu, uyum alt boyutunda ise aralarında anlamlı bir farkın olmadığı tespit edilmiştir. Yapılan analiz sonucunda çocuk sahibi olmayan öğretmenlerin uyum alt boyutu dışındaki diğer tüm alt boyutlarda ortalama puanlarının çocuk sahibi olmayan öğretmenlerin puanlarından daha yüksek olduğu görülmektedir. Buna göre çocuk sahibi olmayan öğretmenlerin çocuk sahibi olan öğretmenlere göre mülteci öğrencilere yönelik "iletişim" ve "yeterlik" alt boyutlarındaki tutumları arasında anlamlı bir farkın olduğu söylenebilir. Buna ilaveten mülteci öğrencilere yönelik çocuk sahibi olmayan öğretmenlerin daha olumlu bir tutuma sahip oldukları söylenebilir. Genel toplamda ise çocuk sahibi olan ve olmayan öğretmenler arasında anlamlı bir farklılığın olmadığı söylenebilir.

\section{Sendika Değişkenine Göre Ortaokullarda Öğrenim Gören Mülteci Öğrencilere Yönelik Öğretmenlerin Tutum Düzeylerine İlişkin Bulgular}

Sendikaya üye olan ve üye olmayan öğretmenlerin mülteci öğrencilere yönelik tutumlarına ilişkin bulgular aşağıdaki Tablo 12' de sunulmuştur.

Tablo 12. Öğretmenlerin çocuk sahibi olma durumu değişkenine göre ortaokullarda öğrenim gören mülteci öğrencilere yönelik tutum düzeylerine ilişkin bağımsız t- testi sonuçları

\begin{tabular}{|c|c|c|c|c|c|c|}
\hline Boyutlar & Sendika Üyeliği & $\mathbf{N}$ & $x^{-}$ & Ss & $\mathbf{t}$ & $\mathbf{p}$ \\
\hline \multirow[t]{2}{*}{ İletişim } & Üye & 538 & 3.27 & .33 & \multirow{2}{*}{1.984} & \multirow{2}{*}{.04} \\
\hline & Üye Değil & 276 & 3.32 & .32 & & \\
\hline \multirow[t]{2}{*}{ Uyum } & Üye & 538 & 2.76 & .42 & \multirow{2}{*}{0.693} & \multirow{2}{*}{.49} \\
\hline & Üye Değil & 276 & 2.78 & .44 & & \\
\hline \multirow[t]{2}{*}{ Yeterlik } & Üye & 538 & 2.61 & .57 & \multirow{2}{*}{0.624} & \multirow{2}{*}{.53} \\
\hline & Üye Değil & 276 & 2.64 & .56 & & \\
\hline \multirow[t]{2}{*}{ Toplam } & Üye & 538 & 2.97 & .31 & \multirow{2}{*}{1.499} & \multirow{2}{*}{.13} \\
\hline & Üye Değil & 276 & 3.00 & .31 & & \\
\hline
\end{tabular}

${ }^{*} \mathrm{p} \leq .05$

Sendikaya üye olan ve olmayan öğretmenlerin mülteci öğrencilere yönelik tutumları arasında yapılan t-testi sonucunda, "iletişim" alt boyutunda aralarında istatistiksel olarak anlamlı bir farklılık olduğu; "uyum", "yeterlik" ve "genel toplam" alt boyutlarında ise aralarında anlamlı bir farkın olmadığı tespit edilmiştir. Yapılan analiz sonucunda iletişim boyutunda sendikaya üye olmayan öğretmenlerin mülteci öğrencilere yönelik tutumları, sendikaya üye olan öğretmenlerden daha iyi düzeyde olduğu söylenebilir. "Uyum”, "yeterlik" alt boyutlarında ve genel toplam olarak da sendikaya üye olan ve olmayan öğretmenlerin mülteci öğrencilere yönelik tutumları arasında anlamlı bir farklılığın olmadığı görülmektedir.

\section{Sınıfında Mülteci Öğrenci Olma Değişkenine Göre Ortaokullarda Öğrenim Gören Mülteci Öğrencilere Yönelik Öğretmenlerin Tutum Düzeylerine İlişkin Bulgular}

Sınıfında mülteci öğrenci olan ve olmayan öğretmenlerin mülteci öğrencilere yönelik tutumlarına ilişkin bulgular aşağıdaki Tablo 13'te sunulmuştur. 
Tablo 13. Öğretmenlerin sınıfında mülteci öğrenci olma değişkenine göre ortaokullarda öğrenim gören mülteci öğrencilere yönelik tutum düzeylerine ilişkin bağımsız t- testi sonuçları

\begin{tabular}{|c|c|c|c|c|c|c|}
\hline Boyutlar & $\begin{array}{l}\text { Sınıfında Mülteci } \\
\text { Öğrenci Durumu }\end{array}$ & $\mathbf{N}$ & $\bar{x}^{-}$ & Ss & $\mathbf{t}$ & p \\
\hline \multirow[t]{2}{*}{ İletişim } & Var & 552 & 3.29 & .31 & \multirow{2}{*}{1.052} & \multirow{2}{*}{.293} \\
\hline & Yok & 262 & 3.27 & .35 & & \\
\hline \multirow[t]{2}{*}{ Uyum } & Var & 552 & 2.81 & .42 & \multirow{2}{*}{-3.691} & \multirow{2}{*}{.000} \\
\hline & Yok & 262 & 2.69 & .45 & & \\
\hline \multirow[t]{2}{*}{ Yeterlik } & Var & 552 & 2.66 & .57 & \multirow{2}{*}{-3.009} & \multirow{2}{*}{.003} \\
\hline & Yok & 262 & 2.53 & .57 & & \\
\hline \multirow[b]{2}{*}{ Toplam } & Var & 552 & 3.01 & .30 & \multirow{2}{*}{-3.319} & \multirow{2}{*}{.001} \\
\hline & Yok & 262 & 2.93 & .33 & & \\
\hline
\end{tabular}

Sınıfında mülteci öğrenci olan ve olmayan öğretmenlerin mülteci öğrencilere yönelik tutumları arasında anlamlı bir farkın olup olmadığını belirlemek amacıyla yapılan t-testi sonucunda, "uyum" ve "yeterlik" alt boyutlarında ve genel olarak (toplam) mülteci öğrencilere yönelik tutumları arasında istatistiksel olarak anlamlı bir farklılık olduğu, bu anlamlı farklılı̆̆ın ise sınıfında mülteci olan öğretmenlerin lehine olduğu belirlenmiştir. Araştırma da, "uyum" ve "yeterlik alt boyutlarında ve genel olarak da (toplamda) sınıfında mülteci öğrenci olan öğretmenlerin mülteci öğrencilere yönelik tutumu, sınıfında mülteci öğrenci olmayan öğretmenlere göre daha olumlu bir tutuma sahip oldukları söylenebilir. Buna karşın, İletişim” alt boyutunda ise sınıfında mülteci öğrenci olan ve olmayan öğretmenler arasında anlamlı bir farklılı̆̆ın olmadı̆̆ı söylenebilir.

\section{Ortaokullarda Öğrenim Gören Mülteci Öğrencilere Yönelik Öğrencilerin Tutumlarına İlişkin Bulgular}

Ortaokullarda öğrenim gören mülteci öğrencilere yönelik öğrencilerin tutumlarına ilişkin aritmetik ortalama ve standart sapma değerleri aşağıdaki Tablo 14 'te belirtilmiştir.

Tablo 14. Mülteci öğrencilere yönelik öğrencilerin tutumlarına İlişkin aritmetik ortalama ve standart sapma değerleri

\begin{tabular}{lcccc}
\hline & $\mathbf{N}$ & $\boldsymbol{x}^{-}$ & Ss & $\begin{array}{c}\text { Öğrencilerin } \\
\text { Tutumları }\end{array}$ \\
\hline $\begin{array}{l}\text { Mülteci Öğgrencilere Yönelik Tutum } \\
\text { (Toplam) }\end{array}$ & 1218 & 2.03 & .45 & Orta Düzeyde \\
\hline
\end{tabular}

Araştırmaya katılan öğrencilerin, mülteci öğrencilere yönelik tutumlarının ( $x=2.03)$ "kararsızım" düzeyinde diğer bir ifade ile "orta düzeyde" oldukları belirlenmiştir. Buna göre öğrencilerin mülteci öğrencilere yönelik tutumlarının "orta düzeyde" olduğu ancak "iyi düzeyde" olmadıkları tespit edilmiştir. Bununla birlikte, öğrencilerin mülteci öğrencilere yönelik en yüksek ve en düşük düzeydeki tutum puanları aşağıdaki Tablo 15 'te gösterilmektedir. 
Tablo 15. Mülteci Öğrenci Yönelik en yüksek ve en düşük tutum puanları

\begin{tabular}{|c|c|c|c|c|}
\hline Sira & En Yüksek Maddeler & $\mathbf{N}$ & $\bar{x}$ & Ss \\
\hline 1 & M4. Mülteci öğrencilerin dilimizi öğrenmelerinden mutluluk duyarım & 1218 & 2.36 & .85 \\
\hline 2 & $\begin{array}{l}\text { M22. Öğretmenlerimizin, mülteci öğrencilere yabancı gibi davranması } \\
\text { istemem. }\end{array}$ & 1218 & 2.33 & .84 \\
\hline 3 & $\begin{array}{l}\text { M9. Mülteci öğrencilerle aynı dinin mensubu olduğumuzdan dolayı onlara } \\
\text { yardım ederim. }\end{array}$ & 1218 & 2.27 & .83 \\
\hline 4 & M6. Mülteci öğrencilerin derslerinde başarılı olmaları beni mutlu eder. & 1218 & 2.26 & .82 \\
\hline 5 & $\begin{array}{l}\text { M13Ülkemizin güzelliklerini tanıtmak için mülteci öğrencilere yardımcı } \\
\text { olurum. }\end{array}$ & 1218 & 2.19 & 1.23 \\
\hline Sira & En Düşük Maddeler & $\mathbf{N}$ & $x^{-}$ & Ss \\
\hline 1 & M2Mülteci öğrencilerle okulda arkadaşlık kurmak için çaba harcarım. & 1218 & 1.89 & .83 \\
\hline 2 & $\begin{array}{l}\text { M10. Mülteci öğrencilerin bizleri kötü alışkanlıklara alıştıracağını } \\
\text { düşünüyorum. }\end{array}$ & 1218 & 1.82 & .81 \\
\hline 3 & $\begin{array}{l}\text { M21. Sınıf içinde yapılan etkinliklerde mülteci öğrencilerle aynı grupta yer } \\
\text { almak isterim. }\end{array}$ & 1218 & 1.82 & .82 \\
\hline 4 & M12. Mülteci öğrencilerle arkadaşlığımı okul dışında da sürdürürüm. & 1218 & 1.79 & .84 \\
\hline
\end{tabular}

Araştırmaya katılan öğrencilerin mülteci öğrencilere yönelik tutum puan ortalamaları incelendiğinde en yüksek puan sırasıyla; "Mülteci öğrencilerin dilimizi öğrenmelerinden mutluluk duyarım" ( $\left.X^{-}=2.36\right)$, “Öğretmenlerimizin, mülteci öğrencilere yabancı gibi davranması istemem" ( $\overline{x=2.33), ~ " M u ̈ l t e c i ~ o ̈ g ̆ r e n c i l e r l e ~ a y n ı ~ d i n i n ~ m e n s u b u ~ o l d u g ̆ u m u z d a n ~ d o l a y ı ~ o n l a r a ~ y a r d ı m ~ e d e r i m " ~}$

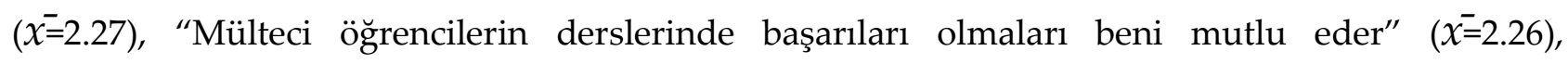
“Ülkemizin güzelliklerini tanıtmak için mülteci öğrencilere yardımcı olurum” $\left(\overline{x^{-}}=2.19\right)$, en düşük tutum ortalama puanları ise sırasılla; "Mülteci öğrencilerle okulda arkadaşlık kurmak için çaba harcarım" ( $\overline{x=1.89), ~ " M u ̈ l t e c i ~ o ̈ g ̆ r e n c i l e r i n ~ b i z l e r i ~ k o ̈ t u ̈ ~ a l ı s ̧ k a n l ı k l a r a ~ a l ı s ̧ t ı r a c a g ̆ ı n ı ~ d u ̈ s ̧ u ̈ n u ̈ y o r u m ” ~}$ $(\overline{x=1.82)}$, "Sınıf içinde yapılan etkinliklerde mülteci öğrencilerle aynı grupta yer almak isterim" $(\overline{x=1.82)}$, “Mülteci öğrencilerle arkadaşlığımı okul dışında da sürdürürüm” ( $\overline{x=1.79)}$ düzeyinde bir tutuma sahip oldukları görülmektedir. Bu ölçekte en yüksek ortalamaya sahip olan ilk 5 madde sirasiyla 4, 22, 9, 6 ve 13. "katılıyorum" düzeyinde, en düşük ortalamaya sahip olan son 4 madde ise sirasiyla 2., 10., 21. ve 12. maddelere ise "biraz katılıyorum" düzeyinde tutum sergiledikleri belirlenmiştir. Diğer bir ifade ile araştırmaya katılan öğrencilerin, mülteci öğrencilerin Türkçe'yi öğrenmelerinden mutlu oldukları, onlara bir yabancı gibi davranmadıkları, aynı dine mensup olmanın gereği olarak onlara yardımcı oldukları, mülteci öğrencilerin derslerinde başarılı olmalarından mutlu oldukları ve onlara ülkemizi tanıtmaktan da memnun oldukları belirlenmiştir. Buna karşın, öğrencilerin, ileriki eğitim hayatlarında, okulda ve okul dışı günlük hayatlarında mülteci öğrencilerle arkadaşlık etmek istemedikleri ortaya konmuştur. Benzer şekilde, mülteci öğrencilerin kendilerine kötü alışkanlıklara alıştıracağını düşünmedikleri ancak öğrencileri sınıf içinde yapılan etkinliklerde mülteci öğrencilerle aynı grupta yer almak istemedikleri tespit edilmiştir. 


\section{Cinsiyet Değişkenine Göre Ortaokullarda Öğrenim Gören Mülteci Öğrencilere Yönelik Öğrencilerin Tutum Düzeylerine İlişkin Bulgular}

Cinsiyet değişkenine göre öğrencilerin, mülteci öğrencilere yönelik tutumlarına ilişkin bulgular aşağıdaki Tablo 16'deasunulmuştur.

Tablo 16. Öğrencilerin cinsiyet değişkenine göre ortaokullarda öğrenim gören mülteci öğrencilere yönelik tutumlarına ilişkin $\mathrm{t}$ - testi sonuçları

\begin{tabular}{lcccccc}
\hline Cinsiyet & $\mathbf{N}$ & $\boldsymbol{x}^{-}$ & Ss & sd & t & p \\
\hline Kadın & 654 & 2.12 & .34 & & & \\
Erkek & 564 & 1.99 & .36 & & & .000 \\
\hline
\end{tabular}

${ }^{*} \mathrm{p} \leq .05$

Yukarıdaki tabloda görüldüğü gibi öğrencilerin, mülteci öğrencilere yönelik tutumları cinsiyete göre anlamlı fark olup olmadığına ilişkin yapılan t-testi sonucunda, öğrencilerin cinsiyetine göre aralarında istatistiksel olarak anlamlı bir farklılık olduğu saptanmıştır. Bu anlamlı farklılığın ise kadınların lehine olduğu tespit edilmiştir. Buna göre kız öğrencilerin erkek öğrencilere göre mülteci öğrencilere yönelik tutumlarının daha olumlu yönde olduğu söylenebilir.

\section{Sınıf Düzeyi Değişkenine Göre Ortaokullarda Öğrenim Gören Mülteci Öğrencilere Yönelik Öğrencilerin Tutum Düzeylerine İlişkin Bulgular}

Öğrencilerin öğrenim gördükleri sınıf düzeyine göre mülteci öğrencilere yönelik tutumlarına ilişkin bulgular aşağıdaki Tablo 17'de gösterilmektedir.

Tablo 17. Öğrencilerin sınıf düzeyi değişkenine göre ortaokullarda öğrenim gören mülteci öğrencilere yönelik tutum düzeylerine ilişkin ANOVA testi sonuçları

\begin{tabular}{llllll}
\hline Siniflar & $\mathbf{N}$ & $\boldsymbol{x}$ & Ss & $\mathbf{F}$ & $\mathbf{p}$ \\
\hline 6.Sinif & 468 & 2.09 & .34 & & \\
7.Sinif & 329 & 2.03 & .39 & 1.581 & .114 \\
8.Sinif & 421 & 2.05 & .35 & & \\
\hline
\end{tabular}

$$
{ }^{*} \mathrm{p} \leq .05
$$

Öğrencilerin, mülteci öğrencilere yönelik tutumları sınıf düzeyi değişkenine göre anlamlı fark olup olmadığına ilişkin yapılan ANOVA-testi sonuçlarına göre, öğrencilerin 6., 7. ve 8. sınıflarda öğrenim görenler arasında istatistiksel olarak anlamlı bir farklılık olmadığı saptanmıştır. Buna göre, araştırmaya katılan öğrencilerin mülteci öğrencilere yönelik tutumlarında "sınıf düzeyi" değişkenin etkili olmadığı söylenebilir.

Sınıfında Mülteci Öğrenci Olma Durumu Değişkenine Göre Öğrencilerin, Mülteci Öğrencilere Yönelik Tutumlarına İlişkin Bulgular

Sınıfında mülteci öğrenci olan ve olmayan öğrencilerin, mülteci öğrencilere yönelik tutumlarına ilişkin bulgular aşağıdaki Tablo 18'de sunulmuştur. 
Tablo 18. Öğrencilerin Sınıfında Mülteci Olma Durumu değişkenine göre Ortaokullarda Öğrenim Gören Mülteci Öğrencilere Yönelik Tutum Düzeylerine İlişkin t - testi sonuçları

\begin{tabular}{ccccccc}
\hline Silfında Mülteci & & & & & & \\
Öğgrenci Olma Durumu & N & $\boldsymbol{x}^{-}$ & Ss & sd & t & p \\
\hline Var & 406 & 2.12 & .34 & & & \\
Yok & 812 & 2.03 & .36 & 1216 & 3.192 & .001 \\
\hline${ }^{*} \mathrm{p} \leq .05$ & & & & & &
\end{tabular}

Yapılan analiz sonucunda sınıfında mülteci öğrenci olan ve olmayan öğrencilerin, mülteci öğrencilere yönelik tutumları arasında istatistiksel olarak anlamlı bir farklılık olduğu ve bu anlamlı farklılığın sınıfında mülteci öğrenci olanlar lehine sonuçlandığı saptanmıştır. Buna göre, sınıfında mülteci öğrenci olan öğrencilerin mülteci öğrencilere yönelik tutumu, sınıfında mülteci öğrenci olmayan öğrencilere göre daha iyi düzeyde olduğu söylenebilir.

\section{TARTIŞMA. SONUÇ}

\section{Birinci Alt Probleme İlişkin Sonuçlar ve Tartışma}

Öğretmenlerin mülteci öğrencilere karşı tutumu genel olarak "iyi düzeyde" olduğu fakat "çok iyi düzeyde olmadığı" tespit edilmiştir. Diğer bir ifade ile öğretmenlerin mülteci öğrencilere karşı iyimser yaklaştıkları, anlayışlı oldukları, kendilerini onların yerine koyarak onları anlamaya çalıştıkları ve yaşadıklarından dolayı onlara önyargısız yaklaşarak adil davrandıkları, derslere motive olmalarını sağladıkları, okula ve sınıfa uyum sağlamalarına yardımcı oldukları, mülteci öğrencilerle birlikte olmaktan memnun oldukları, onlara rehberlik yapmaya, yol göstermeye çalıştıkları söylenebilir. Er ve Bayındır (2015) çalışmalarında öğretmenlerin mülteci öğrencileri ayrıştırmadan bir bütün içinde görmekte ve mülteci öğrencilere karşı ilgili bir şekilde yaklaşmaktadırlar. Kultas (2017) yaptığı araştırmada, gerek konukseverlik gerekse öğretmenlik mesleğinin vermiş olduğu merhamet duygusuyla mültecilere kucak açılması, onların kaygılarıyla kaygılanılması, yardımlarına koşulması bir nebze de olsa acılarını azaltmıştır. Bu araştırma sonuçları elde edilen bulguları destekler niteliktedir. Şensin (2016) yaptığı çalışmada mülteci öğrencilerin eğitim sistemine entegre olmasında bazı problemler ortaya çıkmış ve ilkokul öğretmenleri bu sisteme karşı olumsuz tutuma sahip olmuşlardır.

Mülteci öğrencilere yönelik tutum ölçeğinin alt boyutları incelendiğinde, iletişim boyutunun "çok iyi düzeyde" olduğu tespit edilmiştir. Öğretmenlerin mülteci öğrencilere karşı iletişim kurmak için çok istekli oldukları görülür. ÇOÇA (2015) çalışmasında ise mülteci öğrencilerin yaşadıkları problemlerde, öğretmenlerin çözüm odaklı davranmalarının mülteci öğrencileri mutlu ettiğini ortaya çıkarmıştır. Bu sonuç araştırmayı destekler niteliktedir. Kardeş ve Akman (2018) yaptıkları çalışmada öğretmenler, mülteci çocukların Türk eğitim sistemine entegre olma sorununu çözmek için Türkçe dil eğitimi ve ana sınıfı eğitimi almaları gerektiğini, mülteci çocukların yaşadıkları sarsıntıların tesirinin hafifletilmesi amacıyla toplumsal dayanak hizmetlerinin çoğaltılması ve faal hale getirilmesini önermişlerdir.

Mülteci öğrencilere yönelik öğretmenlerin tutumu "uyum" alt boyutunda "iyi düzeyde“ olduğu belirlenmiştir. Öğretmenlerin, Suriye'de yaşadıklarından dolayı mülteci öğrencilere karşı önyargısız olmaları, mülteci öğrencilerin uyumunu kolaylaştırmıştır. Duman (2016) yaptığı çalışmada öğretmenlerin pedagojik yeterliğinin, mülteci öğrencilere karşı tutumla birlikte onların 
okula uyumunu etkilediğini göstermektedir. Ereş (2015) yaptığı çalışmada mülteci öğrencilerin eğitimlerinin daha iyi bir seviyeye getirilmesi, eğitim planlanmasında bu çocukların her yönden farklı olan yapılarına önem verilmesi ve diğer bileşenler olan okul yöneticileri ve öğretmenler bu çocukların eğitim konusunda desteklenmesi gerektiğini belirtmiştir. Mülteci öğrencilerin okula ve sınıfa pek entegre olamadıklarını vurgulamaktadır.

Mülteci öğrencilere yönelik öğretmenlerin tutumu "yeterlik" alt boyutunda ise "iyi düzeyde" olduğu ortaya çıkmıştır. Ancak, araştırmada öğretmenlerin kendilerini mülteci öğrencilere karşı eğitim-öğretim konusunda çok yeterli görmedikleri ve mülteci öğrencilere karşı uyumlarının çok iyi olmadığı sonucuna ulaşılmıştır. Er ve Bayındır (2015) yaptıkları çalışmada mülteci öğrencilerin eğitilmesi konusunda öğretmenlerin kendilerini yeterli görmediklerini tespit etmiştir. İletişimin önündeki en büyük engellerden biri olan dil farklılığının olması, sınıftaki öğrencilerin de onlara karşı pek olumlu tavır sergilememelerine neden olabilmektedir. Saklan (2018) yaptı̆̆ı araştırmada, mülteci öğrencilerin yaşadığı dil problemi, okul başarılarını ve okula uyumlarını zorlaştırdığı belirtmektedir. Bunların ışığında mülteci öğrencilerin okula ve sınıfa uyumlarının pek olmadığı ve bu durum öğretmenlerin de kendilerini yetersiz görmelerine neden olabilmektedir. Yapılan bu çalışmalar araştırmayı destekler niteliktedir. Yiğit (2015) yaptığı çalışmada mülteci öğrencilere karşı donanımlı olmak için üniversitelerin eğitim bilimleri bölümlerine "Çok kültürlü eğitim" adlı konusu ile ilgili dersler eklenip, öğretmen olduktan sonra yetiştirme ve geliştirme kursları yerine temelden eğitim verilmesi uzun vadede daha yararlı olacağını belirtmiştir.

\section{İkinci Alt Probleme İlişkin Sonuçlar ve Tartışma}

Öğretmenlerin cinsiyetlerine göre mülteci öğrencilere yönelik tutumunda anlamlı bir farklılık görülmemiştir. Yani öğretmenlerin kadın ve erkek olmaları mülteci öğrencilere karşı tutumlarında etkili bir faktör olmadığı tespit edilmiştir. Köse, Bülbül ve Uluman (2017) ve Kanbur'un (2017) yaptığı araştırmada cinsiyet değişkeninin mülteci öğrencilere yönelik öğretmen tutumu üzerinde etki etmediği belirlenmiştir. Bu bulgu, yapılan bu çalışmanın sonucunu destekler niteliktedir.

Öğretmenlerin medeni durumuna göre mülteci öğrencilere yönelik tutumunda uyum boyutu hariç diğerleri anlamlı bulunmamıştır. Uyum boyutunda ise evli olan öğretmenler bekar olan öğretmenlere oranla mülteci öğrencilere yönelik tutumları daha yüksektir. Evlilikte kurulmuş olan aile birliği içindeki öğretmenler, empati kurmalarının daha kolay olması mülteci öğrencilere karşı iyi tutuma sahip olmalarına neden olduğu söylenebilir. Kanbur (2017) yaptığı araştırmada, öğretmenlerin evli ya da bekar olmasının mülteci öğrencilere yönelik tutumunu anlamlı bulmamıştır. Li ve Grineva'nın (2016) yaptıkları araştırma da, kültür ve dinin benzer olması mülteci öğrencilerin okula uyum sağlamalarını kolaylaştırmıştır. SETA'nın (2017) yaptığı araştırmada ise kültürlerin benzer olması sosyal uyumu daha da kolaylaştırdığını belirtmektedir.

Öğretmenlerin çocuk sahibi olma durumuna göre mülteci öğrencilere yönelik tutum puanı iletişim ve yeterlilik boyutu hariç diğerleri arasında farklılık anlamlı bulunmamıştır. İletişim boyutunda çocuk sahibi olmayan öğretmenlerin mülteci öğrencilerle iletişimi daha iyidir. Yeterlilik boyutunda çocuk sahibi olmayan öğretmenlerin mülteci öğrencilere karşı yeterliliği daha yüksektir. Çocuğu olmayan öğretmenlerin mülteci öğrencilere karşı daha duygusal yaklaşarak bütün ilgilerini bu öğrencilere yöneltmeleri, onlara karşı daha iyi tutuma sahip olduklarına neden olduğu söylenebilir. RAM (2018) yaptığı çalışmada da aynı sonuç gözlenmiştir. Kanbur (2017) yaptığ 1 çalışmada ise öğretmenlerin çocuk sahibi olma ya da olmamanın mülteci öğrencilere yönelik tutumunu etkilemediği görülmüştür.

Öğretmenlerin herhangi bir sendikaya üye olma yada olmama durumuna göre, mülteci 
öğrencilere yönelik tutum puanları arasında "iletişim boyutu" hariç diğer alt boyutları arasında anlamlı farklılık bulunmamıştır. Sendikalı olmayan öğretmenlerin mülteci öğrencilere karşı iletişimi daha yüksektir. Sendikaya üye olmayan öğretmenlerin herhangi bir grubun görüşlerini benimsememeleri ve yalnızca kendi yaşantılarıyla tecrübe edinmeleri, mülteci öğrencilere karşı tutumunun daha iyi olduğunu yansıttığı söylenebilir. Genel olarak baktığımızda ise öğretmenlerin sendikalı olup olmaması mülteci öğrencilere karşı tutumlarında etkili değildir. Sendikalı olup olmama durumu alt problemiyle ilgili başka yapılmış herhangi bir araştırmaya rastlanmamıştır.

Öğretmenlerin sınıfında, mülteci olma durumuna göre mülteci öğrencilere yönelik tutum puanları arasında "iletişim boyutu" hariç diğerleri arasında farklılık anlamlı olarak değerlendirilmemiştir. Sınıfında mülteci öğrenci olan öğretmenlerin tutum puanı olmayanlara göre daha yüksektir. Sınıfında mülteci öğrenci olan öğretmenlerin bu öğrencilere karşı önyargısız yaklaşmalarını sağlamakta ve iç içe bir yaşantı geçirmeleri onlara karşı daha iyi tutuma sahip olmalarını sağlamış olabilir. Kanbur (2017) öğretmenlerin, mülteci öğrencilere karşı tutumları; iletişim boyutu arasında anlamlı fark bulunmamış, uyum, yeterlik ve genel toplamda arasında anlamı farklılık bulunmuştur. Yapılan bu çalışma ile benzerlik göstermektedir. Karataş (2015) yaptığı çalışmada sınıflardaki farklı kültürdeki öğrencilere karşı öğretmenlerin tutumu yüksek düzeyde olup eğitim ve öğretimde daha duyarlı oldukları gözlenmiştir. Yapılan bu çalışmalar elde edilen verileri destekler niteliktedir. Kultas (2017) yaptığı çalışmada ülkemizde mülteciler için meydana getirilmiş olan barınma noktalarının içinde veya dışında süreklilik arz etmeyen eğitim amacıyla kurulmuş yapılarda eğitim alan mülteci öğrenciler ülkemizdeki okul çağı mülteci çocukların takribi \%30'unu kapsamaktadır. Göç İdaresi Genel Müdürlüğünün 2016 yılındaki bilgilerine göre bu oran \%13; bir sonraki y1l ise takribi \%30 olmuştur. Bir y1l içinde bu oranın artmasındaki en önemli neden, mülteci çocuklara eğitim verilmesi için açılan süreklilik arz etmeyen yapıların eğitim yapılarının sayıların çoğaltılması olmuştur. Bu da mülteci çocukların eğitiminde önemli bir katkısının olduğunu kanıtlamıştır. Bu gelişmelere rağmen maalesef Türkiye'de okul çağındaki mülteci çocukların \%70'e yaklaşan kısmı bu eğitim faaliyetlerinden yararlanamamaktadır.

\section{Üçüncü Alt Probleme İlişkin Sonuçlar ve Tartışma}

Ortaokulda öğrenim gören öğrencilerin, mülteci öğrencilere karşı tutumu genel olarak “orta düzeyde" olduğu fakat "iyi düzeyde" olmadığ1 tespit edilmiştir. Bu da ortaokulda öğrenim gören öğrencilerin, mülteci öğrencilere yönelik tutumunun olumsuz olmadığını göstermektedir. Bu olumlu bir gelişme olarak değerlendirilmektedir. Şensin (2016) yaptığı çalışmada öğrencilerin mülteci öğrencilere karşı olumlu tutuma sahip oldukları görülmüştür. Bu araştırma yapılan çalışmayı destekler niteliktedir. Diğer bir ifadeyle; öğrencilerimiz mülteci öğrencileri gayet benimseyerek onların bizim dilimizi öğrenmeleri olumlu karşılanıp, bunun vasıtasıyla ülkemizi onlara tanıtmayı istemektedirler. Öğretmenlerin onları dışlamamasından ve sınıf ortamında işlenen derslerde başarılarının artırılmasından gayet hoşnut olacaklarını vurgulamışlardır. Din kardeşliği aralarında köprü görevi görecek, onların zor zamanlarında yardımlarına koşacakları ve bu durumdan da memnun olacaklarını vurgulamışlardır. Gülay (2011) yaptığı çalışmada, mülteci öğrencilerin okula bağlılığını etkileyen arkadaşlarının onlara gösterdiği davranışlar olduğunu vurgulamaktadır. Eğer arkadaşları mülteci öğrencileri kabullenirse okula devamlılık ve istekliliğin artmasını sağlayabilir. Bununla birlikte öğrencilerin, mülteci öğrencilerle ileriki eğitim hayatlarında pek arkadaşlık yapmak istememektedir. Bunu yanı sıra mülteci öğrencilerin kötü alışkanlıkları olmadıklarını ve bundan da olumsuz yönde etkilenmediklerini belirtmelerine rağmen, yinede onlarla sınıf içinde aynı kümede yada aynı etkinlik içinde yer almak istemediklerini vurgulamışlardır. Coşkun ve Emin (2016) yaptığı çalışmada öğrenciler mülteci 
öğrencilere karşı olumsuz davranışlar gösterirlerse mülteci öğrenciler içine kapanır, sosyalleşmelerini engeller ve okula karşı isteksiz olur. Güngör ve Şenel (2018) yaptıkları çalışmada mülteci öğrencilerin çevreleri, okuldaki akranları ve öğretmenleri ile yaşadıkları iletişim problemleri, kendilerini iyi ifade edememelerine neden olmakta, derslerinde de etkin olamadıkları için akademik başarı olarak arkadaşlarından düşük düzeyde kaldıkları ortaya çıkmıştır. Buna ilaveten Yüce (2018) yaptığı araştırmada, mülteci öğrencilerin akademik ve gelişimine uygun olmayan sınıflarda eğitim görmeleri okula karşı isteksiz olmalarına neden olduğunu belirtmektedir. Aydoğdu ve Ayanoğlu (2019) yaptıkları çalışmada, mülteci çocukların kendi çevrelerinde kopup Türkiye'ye gelmesiyle onların da problemleri ortaya çıkmıştır. Eğitimlerinde geri kalmamaları için eğitim sistemine dahil edilmeye çalışılan bu çocukların entegre olamamaların en büyük nedeni konuşulan dil farklılı̆̆ıdır. Bu dil sorunu birçok problemi de beraberinde getirmektedir. Bunların başında uyum probleminde söz edilebilir. Eğitim sistemine uyumun sağlanamaması öğretmen ve o sınıfta okuyan öğrenciler içinde oldukça yorucu bir süreci başlatmaktadır. Mülteci çocukların dil problemi yaşamaları onların kendilerini ifade etmelerini, kabiliyetlerini ve yeterliklerini ortaya koymada ve okula aidiyetlerini engellemektedir.

\section{Dördüncü Alt Probleme İlişkin Sonuçlar ve Tartışma}

Öğrencilerin cinsiyete göre mülteci öğrencilere yönelik tutumları arasında farklılık anlamlı bulunmuştur. Kızların tutum puanları erkeklere göre daha yüksektir. Kız öğrencilerin erkeklere göre mülteci öğrencilere karşı tutumlarının daha iyi bir düzeyde olduğu söylenebilir. Kız öğrencileri erkeklere göre daha duygusal ve empati kurabilme becerisinin daha yüksek olması nedeniyle mülteci öğrencilere karşı daha iyi tutuma sahip oldukları söylenebilir. Salur ve Koçoğlu (2018) yaptığ1 araştırmada eğitim ve ilahiyat fakültesi öğrencilerin göç ve mülteci sorununa ilişkin cinsiyete göre tutumlarında kızların erkeklere göre daha olumlu bir tutuma sahip oldukları görülmüştür. Kadınların erkeklere oranla daha duygusal olmasından kaynaklandığı söylenebilir. Bu bulgu araştırma sonuçlarını destekler niteliktedir. RAM (2018) yaptığı çalışmada ilkokul 3. ve 4. sınıfa giden öğrencilerin mülteci öğrencilere karşı tutumlarında anlamlı bir fark bulunmamıştır. Bunun sebebi olarak öğrencilerin gelişimsel olarak küçük yaşta olduğu söylenebilir. Kirişçi (2014) yaptığı çalışmada mülteci öğrencilerin karma eğitime alışamadıkları için okula uyum sağlamakta güçlük çektikleri gözlenmiştir.

Öğrencilerin sınıf düzeyine göre mülteci öğrencilere yönelik tutumları arasında anlamlı bir fark bulunmamıştır. Öğrencilerin farklı sınıfta öğrenim görmeleri onların mülteci öğrencilere yönelik tutumları üzerinde etkili olmamıştır. RAM (2018) yaptığı çalışmada da öğrencilerin farklı sınıflarda olması mülteci öğrencilere yönelik tutumunu etkilemediği görülmüştür. Yapılan araştırma, bu araştırma sonucunu destekler niteliktedir.

Yapılan araştırmada, öğrencilerin sınıfında mülteci öğrenci olup olmama durumuna göre mülteci öğrencilere yönelik tutumları arasında anlamlı bir farklılık olduğu belirlenmiştir. Sınıfında mülteci öğrenci olanların tutum puanı olmayanlarınkinden daha yüksektir. Mülteci öğrenci olan sınıfta öğrencilerin tutumları, mülteci öğrenci olmayan öğrencilerin tutumlarından daha iyidir. Öğrencilerin mülteci öğrencilerle ortak yaşantı içinde olmaları onlara karşı tutumlarının daha iyi olmasına neden olduğu söylenebilir. Coşkun ve Emin (2016) yaptıkları çalışmada öğrencilerin mülteci öğrencilere karşı iyi ve hoş davranması mülteci öğrencilerin okula uyumunu kolaylaştırır. Arkadaşları tarafından dışlanan mülteci öğrenciler ise okula karşı olumsuz tutuma sahip olurlar. SETA (2017) yaptığı çalışmada, mülteci öğrencilerin sınıflara eşit şekilde dağıtılması başarıyı olumlu yönde etkilediğini tespit etmiştir. Sınıflarda mülteci öğrencilerin fazla olması gruplaşmaya neden olabilmektedir. 
Buraya kadar yapılan analizler sonucunda ortaya konulan temel düşünce;insanlık tarihimiz içerisinde en büyük zenginlik kaynağımız, kültürel mirasımız içerisinde yaşattı̆̆ımız yardımseverlik, hayırseverlik, hoşgörülü olma, insana saygı, mazluma ve düşküne yardım etme gibi vb. insani değerlerle mazlumlara kucak açmamızdır. Böyle yüksek değerlere sahip bir millet ancak uygarlık düzeyine ulaşabilir

\section{ÖNERİLER}

Mülteci öğrencilerin ve beraberinde öğretmenlerin eğitim alanında yaşadıkları sorunların azaltılması adına getirilebilecek öneriler aşağıda sunulmuştur.

1. Öğretmenlerin mülteci öğrencilere yönelik tutumlarının iyi düzeyde olduğu ancak çok iyi bir düzeyde olmaması nedeniyle, öğretmen tutumlarının daha olumlu olmasına yönelik eğitsel etkinlikler bağlamında seminerler, konferanslar, paneller vb. düzenlenebilir.

2. Araştırmada, mülteci öğrencilerin dil farklılığ öğretmenler için sorun oluşturduğu, bu durum mülteci öğrencilerin sinıfa uyumlarını zorlaştırdığı, dolayısıyla tüm bu sorunların çözümüne yönelik olarak, mülteci öğrenciler için Türkçe dil eğitimine ayrı bir önem verilmeli ve dil öğrenmeye yönelik proje çalışmaları yapılabilir, bu konuda imkânlar daha da arttırılabilir.

3. Mülteci öğrencilerin dil farklılığ öğretmenlerin kendilerini bu konuda yeterli düzeyde görmedikleri ve dolayısıyla da bu öğrencilerle sınıfta uyum sorunu yaşamaktadır. Bu sebeple, hem uyum sorunu olan mülteci öğrenciler için hem de öğretmenler için uyum politikaları yürütülerek ve çeşitli sosyal etkinlikler düzenlenerek uyum sorununun aşılması hılandırılabilir.

4. Ortaokul öğrencilerinin, mülteci öğrencilere yönelik tutumlarının orta düzeyde olması nedeniyle önyargıların giderilmesi adına mülteci öğrencilerin sınıf içinde diğer öğrencilerle etkileşiminin arttırılmasına yönelik çeşitli eğitsel ve sportif etkinler/faaliyetler düzenlenebilir.

5. Türkiye'de bir süre daha kalacakları düşünülerek mülteci öğrencilere yönelik öğretmenlerin ve öğrencilerin tutumlarını geliştirmeye yönelik Türkiye'yi tanıma ve tanıtma adına daha kapsamlı araştırmalar yapılabilir.

6. Mülteci öğrencilere yönelik tutum çalışmasını sadece ortaokul kademesinde değil diğer eğitim kademelerinde yapılarak araştırmalar yapılabilir.

7. Mülteci öğrencilerin, öğretmenlerine ve arkadaşlarına yönelik tutumu belirlemek için nitel veya nicel çalışmalar yapılabilir.

\section{KAYNAKLAR}

Akalın, A. (2016). Türkiye"ye gelen suriyeli göçmen çocukların eğitim sorunları. (Yayımlanmamış Yüksek Lisans Tezi). Aydın Üniversitesi Sosyal Bilimler Enstitüsü, İstanbul.

Akalın, A. (2016 ). Son düzenlemeler ışığında göçmen ev işçileri piyasası . Saha, (2), 40-45.

Akdeniz, Y. (2018). Türkiye'de yaşayan suriyeli mülteci öğrencilerin uyum sorunları. Yüksek Lisans

Tezi. Sakarya Üniversitesi Eğitim Bilimleri Enstütisi, Sakarya.

Akşit, G., Bozok, M., \& Bozok, N. (2015 ). Zorunlu göç, sorunlu karşılaşmalar: Hisar köyü,

Nevşehir'deki suriyeli göçmenler örneği. Maltepe Üniversitesi Fen-Edebiyat Fakültesi Dergisi, 1(2), 92-116.

Alkurt, A. (2016). A Comparative policy analysis of syrian refugee education: Turkey and Lebanon. Is it likely to design a standardised education for all? . (Yayımlanmamış Yüksek Lisans Tezi).

Sabancı Üniversitesi Sosyal Bilimler Enstitüsü, Ankara.

Aras, B. ve Yasun, S. (2016). The educational opportunities and challenges of syrian refugee students in 
Turkey: Temporary education centers and beyond. Istanbul Policy Center-Sabanci UniversityStiftung Mercator Initiative.

Aydoğdu, F., \& Ayanoğlu, M. (2019). Suriyeli çocuklara eğitim veren ilkokul öğretmenlerinin suriyeli çocuklarla ilgili yaşadiklari sorunlarin incelenmesi. Ocak, 4, 2020 tarihinde http://earsiv.erzincan.edu.tr/xmlui/bitstream/handle/20.500.12432/1200/aydo\%C4\%9Fdu \%20ve\%20ayano\%C4\%9Flu2019.pdf?sequence=1\&isAllowed $=\mathrm{y}$

Bahadır, H., \& Uçku, R. (2016). İzmir'in bir mahallesinde yaşayan 6-17 yaş arasındaki suriyeli çocukların çalışma durumları ve çalışma durumlarını etkileyen etmenler. Dokuz Eylül Üniversitesi Tip Fakültesi Dergisi, 30(3), 117-124.

Bozkurt, S. (2018). Mülteci öğrencilerin eğitimine ilişkin öğretmen algıları. (Yayımlanmamış Yüksek Lisans Tezi). Üsküdar Üniversitesi Sağlık Bilimleri Enstitüsü, İstanbul.

Coşkun, İ., \& Emin, M. (. (2016). Türkiye"deki Suriyelilerin eğitiminde yol haritası firsatlar ve zorluklar. istanbul. SETA:http://file.setav.org/Files/Pdf/20160906135243_turkiyedekiuriyelilerinegitiminde-yol-haritasi-pdf.pdf adresinden Ağustos 28, 2018 tarihinde indirilmiştir.

Coşkun, İ., \& Emin, M. N. (2018 ). Türkiye'de göçmenlerin eğitimi: mevcut durum ve çözüm önerileri. İlke Kültür Ĕ̆itim Derneği,1-16.

https://ilke.org.tr/images/yayin/pdf/turkiyede gocmenlerin egitimi mevcut durum ve cozum onerileri.pdf 12.04.2019 tarihinde indirilmiştir.

ÇOÇA. (2015). Süriyeli çocukların Türkiye devlet okullarındaki durumu. (İ. B. Birimi, Dü.) Politika ve Uygulama Önerileri: http://cocuk.bilgi.edu.tr/wp-content/uploads/2015/09/SuriyeliCocuklar-Egitim-Sistemi-Politika-Notu adresinden 01 18, 2017 tarihinde indirildi.

Duman, T. (2016). Sosyal uyumu sağlamak için Suriyelilerin eğitiminin önemi. (H. M. Paksoy ve diğerleri) II. Ortadoğu Konferansları: Ortadoğu'daki Çatışmalar Bağlamında Göç Sorunu, İçinde, (s. 46-54). Kilis:Kilis 7 Aralık Üniversitesi Matbaası.

Er A.K ve Bayındır, N. (2015). İlkokula giden mülteci çocuklara yönelik sınıf öğretmenlerinin pedagojik yaklaşımları. Uluslararası Sosyal ve Ĕ̆itim Bilimleri Dergis, 2(4), 175-185.

Erdem, C. (2017). Sınıfında mülteci öğrenci bulunan sınıf öğretmenlerinin yaşadıkları sorunlar ve çözüme dair öneriler. Medeniyet Eğitim Araştırmaları Dergisi, 1(1), 26-42.

Ereş, F. (2015). Türkiye' de göçmen eğitimi sorunsalı ve göçmen eğitiminde farklılı̆̆ın yönetimi. Çankırı Karatekin Üniversitesi, Sosyal Bilimler Enstitüsü Dergisi, 6(2), 17-30.

Geçici Koruma Yönetmeliği. (2014). Geçiş Hükümleri 6220 (Cilt 55). Resmi Gazete.

George, D., \& Mallery, M. (2010). SPSS for windows step by step: A simple guide and reference, 17.0 update (10a ed.). Boston: Pearson.

Gülay, H. (2011). 5-6 Yaş grubu çocuklarda okula uyum ve akran ilişkileri. Elektronik Sosyal Bilimler Dergisi, 36(36), 1-10.

Güngör, F., \& Şenel, E. (2018). Yabanc1 uyruklu ilkokul öğrencilerinin eğitim- öğretiminde yaşanan sorunlara ilişkin öğretmen ve öğrenci görüşleri. Anadolu Journal of Educational Sciences International, 8(2), 124-173.

Hyson, M. (2004). The emotional development of young children: Building an emotioncentered curriculum. New York, USA: Teachers College Press.

İlksen Kanbur, N. (2017). İlkokulda görev yapan öğretmenlerin mülteci öğrencilere yönelik tutumlarının incelenmesi. (Yayımlanmamış Yüksek Lisans Tezi). Sakarya Üniversitesi Eğitim Bilimleri Enstitüsü, Sakarya.

Kağıtçıbaşı, Ç. (2012). İnsan ve İnsanlar. (13. Baskı ). İstanbul: Evrim Yayınevi

Karasar, N. (2008). Bilimsel Araştırma Yöntemleri. Ankara: Nobel Yayıncılık. 
Karataş, S. (2015). Teachers' views on multicultural education: Sample of Antalya. Anthropologist, 19(2), 373-380.

Kardeş, S., \& Akman, B. (2018). Suriyeli mültecilerin eğitimine yönelik öğretmen görüşleri. Elementary Education Online, 1224-1237.

Kılcan, B., Çepni, o, \& Kılınç, A.Ç. (2017). Mülteci öğrencilere yönelik tutum ölçeğinin geliştirilmesi. Journal of Human Sciences, 14(2), 1045-1057.

Kirişçi, K. (2014). Misafirliğin Ötesine Geçerken Türkiye'nin Suriyeli Mülteciler Sınavı. (Çeviren: S. Karaca). Brookings Enstitüsü Stratejik Araştırmalar Kurumu (USAK).

Koçoğlu, E., \& Salur, M. (2018). Üniversite öğrencilerinin göç ve mülteci sorununa ilişkin tutumları. Kırşehir Ĕ̆itim Fakültesi Dergisi, 19(3), 2408-2425.

Köse, N. ,. (2019). Sınıf öğretmenlerinin mülteci öğrencilere yönelik tutumlarının çeşitli değişkenler açısından incelenmesi. Journal of Continuous Vocational Education and Training, 2(1) , 16-29.

Kultas, E. (2017). Türkiyede buluna eğitim çă̆ındaki suriyeli mültecilerin eğitim sorunu. (Yayımlanmamış Yüksek Lisans Tezi). Yüzüncü Yıl Üniversitesi Eğitim Bilimleri Enstitüsü, Van .

Li, X. V. (2016). Academic and social adjustment of high school refugee youth in Newfoundland. Tes Canada Journal, 34(11), 51-71.

Massey, D., Arango, J., Hugo, G., Kouaouci, A., Pellegrino, A., \& Taylor, J. (1998). Worlds in motion: Understanding International Migration at the End of the Millennium. Oxford:Oxford University Press. https://journals.sagepub.com/doi/pdf/10.1177/019791830003400314

Özdamar, K. (2004). Paket Programlar İle İstatistiksel Veri Analizi. Eskişehir:Kaan Kitapevi.

Polat, F. (2012). Türkiye'de öğrenim gören yabancı uyruklu ilköğretim öğrencilerinin karşılaştıkları sorunlar ve çözüm önerileri. (Yayımlanmamış Yüksek Lisans Tezi). Elazı̆̆ Fırat Üniversitesi Eğitim Bilimleri Enstitüsü, Elazı̆̆.

Pumariega, A. J., Rothe, E., \& Pumariega, J. B. (2005). Mental health of immigrants and refugees.Community Mental Health Journal,41(5),581-597.

RAM. (2018). İzmir ili Konak ilçesi ilkokullarındaki öğretmen ve öğrencilerin,suriyeli öğrencilere yönelik sosyal kabul düzeylerinin tespit edilmesi. 11 25, 2018 tarihinde Konak rehberlik ve araştırmamerkezi:http://konakram.meb.k12.tr/meb_iys_dosyalar/35/01/164246/dosyalar /2018_10/08115626_YZMYR_YLY_KONAK_YLYESY_04.10.2018.pdf adresinden alınd1

Reyes, M. R., Brackett, M. A., Rivers, S. E., White, M., \& Salovey, P. (2012). Classroom emotional Climate, Student Engagement, and Academic Achievement. Journal of Educational Psychology, 104 (3), 700-712.

Sağlam, H. İ. (2017). Sınıf öğretmenlerinin mülteci öğrencilere yönelik tutumlarının çeşitli değişkenler açısından incelenmesi. Sakarya University Journal of Education, 7(2), 310-323.

Saklan. (2018). Türkiye'deki Suriyeli eğitim çağı çocuklarının eğitim süreçleri üzerine bir çözümleme. (Yayımlanmamış Doktora Tezi). Ankara Üniversitesi Eğitim Bilimleri Enstitüsü, Ankara.

Sirin, S. R. ve Rogers Sirin, L. (2015). Suriyeli mülteci çocukların eğitim ve ruh sağlı̆̆ı ihtiyaçları (s. 13). Washington, DC: Göç Politikası Enstitüsü.

SETA. (2017, 02 07). Siyaset, Ekonomi ve Toplum Araştırmaları Vakfı 2018 tarihinde Engelleri aşmak: Türkiye'de Şriyeli çocukları okullaştırmak.: https://setav.org/assets/uploads/2017/11/Engelleri-A\%C5\%9FmakT\%C3\%BCrkiye\%E2\%80\%99de-Suriyeli-\%C3\%87ocuklar\%C4\%B1- adresinden 09.04.2019 tarihinde alınmıştır. 
Şeker, B. D., \& Aslan, Z. (2015). Eğitim sürecinde mülteci çocuklar:Sosyal psikolojik bir değerlendirme. Kuramsal Ĕ̆itimbilim Dergisi, 8(1), 86-105.

Şensin, C. (2016). Sınıf öğretmenlerinin suriye'den göçle gelen öğrencilerin eğitimlerine ilişkin görüşlerinin değerlendirilmesi. (Yayımlanmamış Yüksek Lisans Tezi). Bursa Uludağ Üniversitesi Eğitim Bilimleri Enstitüsü, Bursa.

UNICEF. (2016). Türkiye' deki Suriyeli çocuklar raporu. 18.06.2016 tarihinde https://www.unicefturk.org/suriye/Suriyeli_Cocuklar_Bilgi_Notu_Nisan\%202016_1.pdf adresinden edinilmiştir

Yiğit, T. (2015). Uygulamalar ve sorunlar bă̆lamında Türkiye'de sığınmacı çocukların eğitimi. (Yayımlanmamış Yüksek Lisans Tezi). Kırşehir Evran Üniversitesi Sosyal Bilimler Üniversitesi, Kırşehir.

Yonca, A. V. (2014). Suriyeli göçmenlerin sorunları çalıştayı sonuç raporu. Mersin: Mersin Üniversitesi Bölgesel İzleme Uygulama Araştırma Merkezi.

Yüce, E. (2018). Geçici koruma altında bulunan suriyeli öğrencilerin okula uyumları. (Yayımlanmamış Yüksek Lisans Tezi). Ankara Üniversitesi Eğitim Bilimleri Enstütisi, Ankara. 